\title{
ЕКСПЕРИМЕНТАЛЬНЕ ВИЗНАЧЕННЯ ПАРАМЕТРІВ ЖОРСТКОСТІ ПРОМІЖНИХ СКРІПЛЕНЬ ТИПУ ДО В УМОВАХ ПРОМИСЛОВОГО ТРАНСПОРТУ
}

\section{THE EXPERIMENTAL RESULTS HARDNESS INTERMEDIATE FASTENING ELEMENTS SUCH AS DO, OBTAINED FOR AN INDUSTRIAL RAILWAY}

Вступ. Основними параметрами, що формують вертикальну жорсткість і жорсткості скріплень ДО при горизонтальному поперечному вигині і крученні рейки $\epsilon$, як було встановлено на підставі аналізу, виконаного в статті [1], коефіцієнт постілі підкладки $C_{\text {под }}\left(\kappa H / \mathcal{M}^{3}\right) \quad$ i жорсткість костилів при їх поперечному віджиманні.

Аналіз досліджень і публікацій. Для умов магістрального залізничного транспорту найбільш застосовуваною $\epsilon$ загальна розрахункова схема рейкової колії у вигляді балок - рейок, які спираються на суцільну пружну основу, що має постійні пружні характеристики. Результати експериментальних досліджень просторових пружних характеристик пружньої основи при деревяних шпалах зі скріпленням типу ДО наведено в роботах О.П. Єршкова, M.I. Карпущенка, О.I. Гасанова, Г.М. Шахунянца та інших вчених.

Основна частина. Для визначення величини коефіцієнта постелі дерев'яних шпал в умовах промислового транспорту i змін цієї величини в процесі експлуатації колії були використані результати експериментальних робіт, проведених на металургійних і гірничодобувних підприємствах України 3 використанням методики, докладно викладеною в статті [2].

Роботи проводилися на шести дослідних ділянках, на яких обертався різний рухомий склад і які розрізнялися термінами служби колії. Експлуатаційні характеристики ділянок наведено в табл. 1.

Таблиця 1

Характеристики дослідних ділянок для визначення параметрів вертикальної жорсткості скріплень ДО

\begin{tabular}{|c|c|c|c|c|}
\hline $\begin{array}{c}\text { Номер } \\
\text { ділянки }\end{array}$ & Тип рухомого складу & $\begin{array}{c}\text { Осьові } \\
\text { навантаження, } \\
\kappa H\end{array}$ & $\begin{array}{c}\text { Швидкість руху, } \\
\kappa м / \text { год }\end{array}$ & $\begin{array}{c}\text { Термін } \\
\text { служби колії, } \\
\text { роки }\end{array}$ \\
\hline 1 & 2 & 3 & 4 & 5 \\
\hline 1 & Чавуново3 $80 \mathrm{~T}$ & 353 & $<5$ & 5 \\
\hline 2 & Чавуново3 $80 \mathrm{~T}$ & 353 & $<5$ & 5 \\
\hline 3 & Шлаково3 $11 \mathrm{~m}^{3}$ & 211 & $5-7$ & 0 \\
\hline 4 & Думпкар 6-ВС-60 & 216 & $15-20$ & 7 \\
\hline 5 & Думпкар 6-ВС-60 & 216 & $10-15$ & 10 \\
\hline 6 & Думпкар 6-ВС-60 & 216 & $5-10$ & \\
\hline
\end{tabular}


На всіх ділянках були укладені рейки типу Р65, епюра шпал - 1840 шт./км.

Вертикальні навантаження на шпали визначалися за допомогою силомірних підкладок, які заздалегідь були протаровані на гідравлічному пресі.

При виконанні експериментальних робіт визначалися вертикальні переміщення рейок і вертикальні переміщення шпал за допомогою відеоцифрової системи визначення переміщення [3].
На кожній досліджуваній ділянці було випробувано не менше 20 шпал.

На рис. 1, як приклад, наведені пружні характеристики скріплення ДО при навантаженні вертикальною силою і при подальшому розвантаженні. Характеристики одержані в результаті обробки даних експерименту на ділянці №4 при русі думпкара 6-ВС-60 із швидкістю 12,5 км/год $(3,47 \mathrm{~m} / \mathrm{c})$. Максимальне навантаження на вузол скріплення склало 49,7 кН.

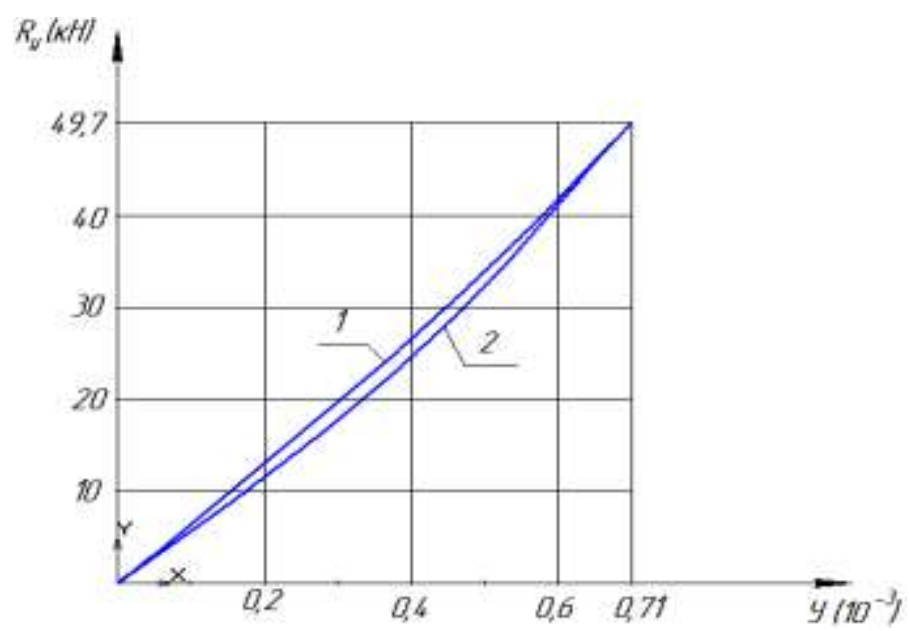

Рис. 1. Вертикальні пружні характеристики скріплення ДО при русі думпкара 6-ВС-60: 1 - при навантаженні скріплення; 2 - при розвантаженні

Вертикальні пружні характеристики скріплення ДО близькі до лінійних. Максимальні вертикальні пружні переміщення в скріпленні склали в даному випадку 0,71 мм, вертикальна жорсткість $7,02 \cdot 10^{4} \mathrm{\kappa H} / \mathrm{M}$.

Коефіцієнт постелі підкладки розраховувався на підставі дослідних даних як, $\kappa H / \mu^{3}$,

$$
C_{\text {nод }}=\frac{\Delta R_{y}}{\Delta y \cdot \omega_{\Pi}},
$$

де $\Delta R_{y}$ - змінення вертикальних навантажень на скріплення в робочому діапазоні $(\kappa H)$;
$\Delta y$ - змінення вертикальних пружніх деформацій у скріпленні, відповідних робочому діапазону навантажень, $\boldsymbol{м}$; ${ }_{2}^{2} \omega_{\Pi}-$ площа підкладки скріплення ДО,

Виконані експериментальні роботи показали, що в процесі експлуатації коефіцієнт постелі підкладки знижується. Це можна пояснити змінами механічних характеристик деревини шпали в результаті процесів деструктуризации целюлози, процесів гниття деревини, змін їі вогкості і ряду інших. Аналіз впливу експлуатаційних чинників колії на коефіцієнт постелі підкладки, виконаний 3 використанням коефіцієнтів кореляції, показав, що головним чинником є термін служби колії. 
На рис. 2 наведено графік залежності коефіцієнта постелі підкладки від термінів служби колії, одержаний на підставі даних проведених експериментів.
Ця залежність апроксимована показовою функцією, емпіричні коефіцієнти якої одержані методом якнайменших квадратів 3 використанням вбудованої функції табличного процесора Excel.

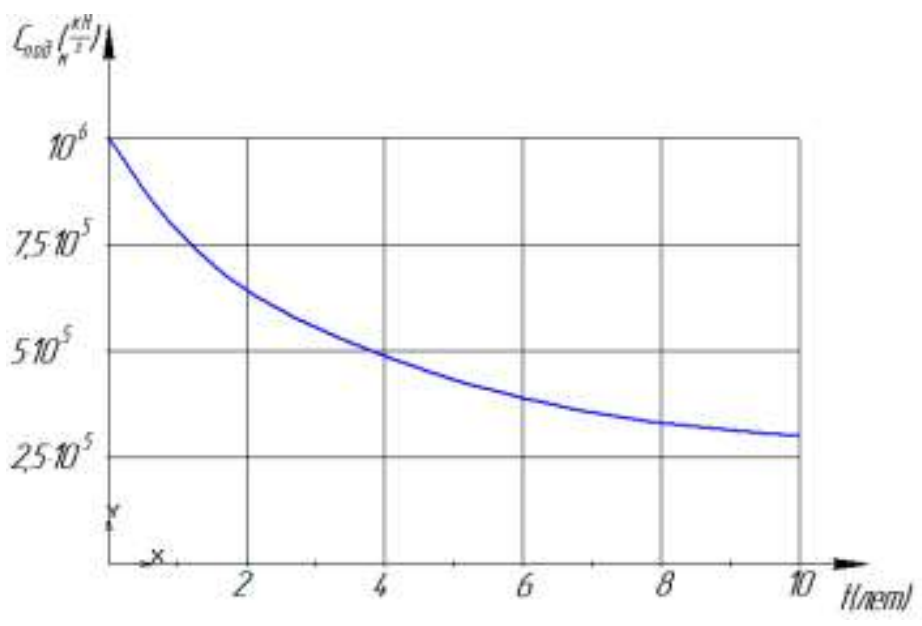

Рис. 2. Графік залежності коефіцієнта постелі підкладки від термінів експлуатації колії

Отримана емпірична залежність має вигляд, $\kappa H / \mu^{3}$,

$$
C_{\text {nod }}=9,996 \cdot 10^{5}-3,955 \cdot 10^{5} t^{0,204} .
$$

Слід зазначити про значний розкид даних, одержаних у результаті цих експериментів. Так, значення вертикальних пружних деформацій скріплення ДО, одержані для однакових значень вертикального навантаження, яке було визначено на шпалах однієї партії i укладених на одній рейковій ланці, могли відрізнятися на $20 \%$ і більше. Мабуть, це пояснюється широким діапазоном, у якому змінюються механічні характеристики деревини шпал. Для рівняння (2) середня помилка апроксимації складає 16,4 \%.

Залежність зміни коефіцієнта постелі підкладки від терміну служби колії дозволяє одержати, використовуючи рівняння, які отримані в статті [1], функції зміни жорсткостей скріплення ДО при вертикальному вигині і при крученні рейки в процесі експлуатації:

$$
\left.\begin{array}{l}
C_{y}=6,24 \cdot 10^{4}-2,47 \cdot 10^{4} t^{0,204}(\kappa H / \mathcal{M}) \\
C_{\varphi}=495,5-196,06 t^{0,204}\left(\kappa H \cdot{ }_{\mu} / p a \partial\right)
\end{array}\right\} .
$$

Для визначення жорсткості костилів при їх поперечному віджиманні, узгодження роботи яких визначає жорсткість скріплення ДО при горизонтальних поперечних вигинах рейки, був використаний пристрій, загальний вигляд якого наведено на рис. 3.

Пристрій складається 3 рамки 1 має спеціальні відгини 2, за допомогою яких захоплюється головка і підошва рейки 3 боку осі колії. Навантаження на торець шпали задавалося гідравлічним домкратом ДГ-5, шток якого упирався в торець шпали, а основа - у приварену до рамки пластину 3. Значення навантаження фіксувалися за манометром, вмонтованим у циліндр домкрата. Переміщення шпали щодо підошви рейки визначалися індикатором ІЧ-10. 


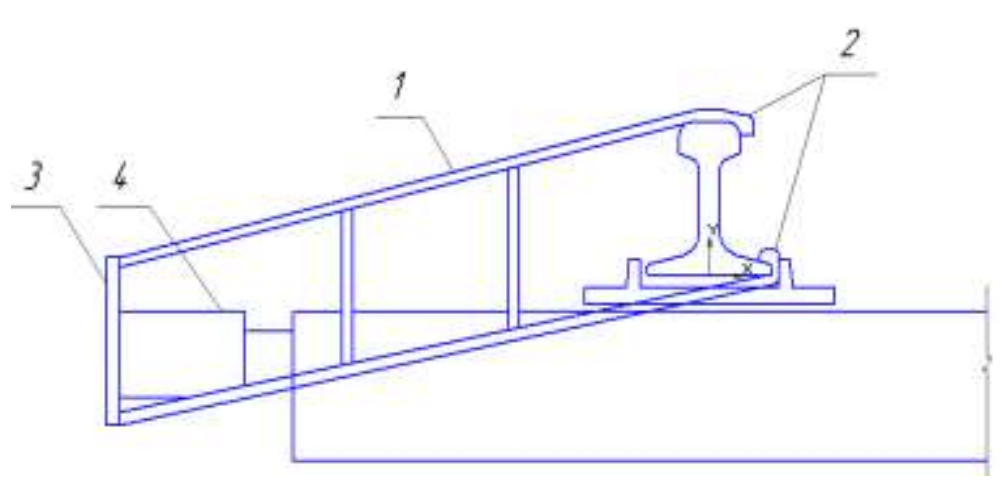

Рис. 3. Прилад для визначення поперечних переміщень шпали:

1 - рамка; 2 - захоплювачі; 3 - пластина; 4 - домкрат

Перед початком дослідження костилі добивалися, баласт у торця шпали відкопувався на глибину 10 см. Для виключення впливу сил тертя шпали по баласту рейкову нитку вивішували на висоту 15-20 мм двома домкратами ДГП-8. Після цього на шпалу встановлювався пристрій, домкрат, індикатор переміщення і починалися випробування.

Навантаження на шпалу прикладалося східчасто по 5 кН до досягнення переміщень шпали 0,6 мм, що $є$ реальними переміщеннями підошви рейки в колії при русі в кривій радіусом 350 м екіпажа 3 осьовими навантаженнями більше 343 кН
[2]. Достатнім виявлявся рівень навантажень, як правило, 38-40 кН для нових шпал і 20-25 кН для старопридатних.

Випробування були проведені на восьми ділянках, експлуатаційні характеристики яких наведено в табл. 2. На кожній ділянці було випробувано не менше 25 шпал.

На рис. 4 наведено, як приклад, пружні характеристики скріплення ДО при горизонтальному вигині рейки, одержані на підставі статистичної обробки даних дослідів на ділянках №1 i №4 (термін служби колії 2 і 10 років відповідно).

Таблиця 2

Характеристики досліджуваних ділянок для визначення параметрів вертикальної жорсткості костилів при віджиманні

\begin{tabular}{|c|c|c|c|c|c|}
\hline \begin{tabular}{|c} 
№ \\
ділян- \\
ки \\
\end{tabular} & Тип рухомого складу & $\begin{array}{c}\text { Осьове } \\
\text { наванта- } \\
\text { ження, } \kappa H\end{array}$ & 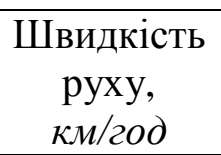 & План лінії & $\begin{array}{c}\text { Термін } \\
\text { служби } \\
\text { колії, роки }\end{array}$ \\
\hline 1 & 2 & 3 & 4 & 5 & 6 \\
\hline 1 & Чавуновоз $50 \mathrm{~T}$ & 201 & $<5$ & Пр & 2 \\
\hline 2 & Чавуновоз $50 \mathrm{~T}$ & 201 & $<5$ & Kp R300 м & 7 \\
\hline 3 & Шлаковоз $11 \mathrm{~m}^{3}$ & 211 & $5-10$ & Kp R650 м & 5 \\
\hline 4 & Шлаковоз 11 м $^{3}$ & 211 & $5-10$ & Пр & 10 \\
\hline 5 & Візки для ізложниць & 346 & $<3$ & $\Pi p$ & 6 \\
\hline 6 & $\begin{array}{l}\text { Візки для ізложниць } \\
4-120-550\end{array}$ & 346 & $<3$ & Пр & 8 \\
\hline 7 & Платформа чавуновоза 70 т & 245 & $5-10$ & Kp R450 м & 0 \\
\hline 8 & Платформа чавуновоза 70 т & 245 & $5-10$ & $\Pi p$ & 12 \\
\hline
\end{tabular}




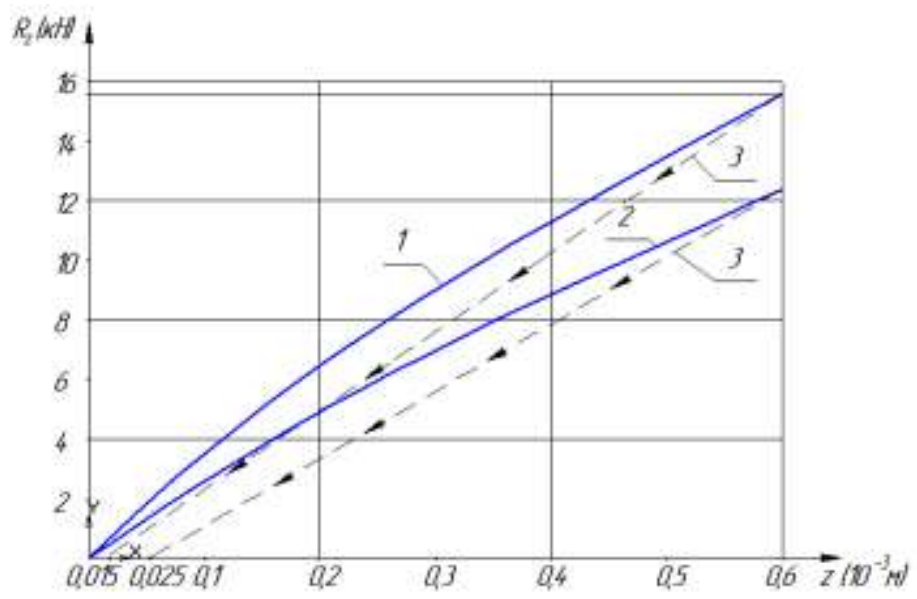

Рис. 4. Пружні характеристики скріплення ДО при бокових переміщеннях шпал: 1 - термін служби колії 2 роки; 2 - термін служби колії 10 років;

3,4 - пружні характеристики при розвантаженні скріплень

Вплив експлуатаційних чинників колії на величини жорсткостей скріплення ДО при горизонтальному вигині рейки $C_{z}$ оцінювався коефіцієнтами кореляції. Най- значущішим $є$ термін служби колії. $\mathrm{y}$ процесі експлуатації жорсткість $C_{z}$ зменшується, залежність цієї величини від терміну служби нелінійна (рис. 5).

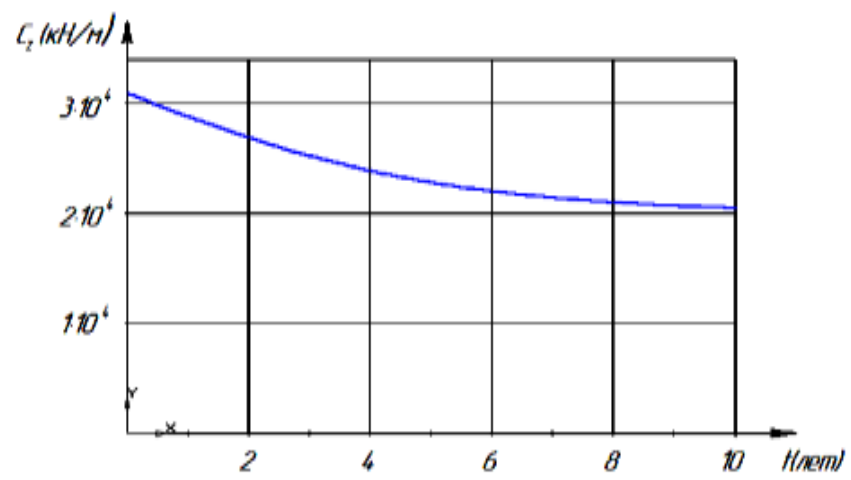

Рис. 5. Графіки залежності горизонтальної поперечної жорсткості скріплення ДО від терміну експлуатації колії

Ця залежність була апроксимована показовим рівнянням, $\kappa H / м$,

$$
C_{z}=3,15 \cdot 10^{4}-0,604 \cdot 10^{4} t^{0,191},
$$

де $t$ - термін експлуатації колії, роки.

Середня помилка апроксимації для рівняння (4) складає 7,8 \%.

Вплив інших експлуатаційних чинників на горизонтальну поперечну жорсткість виявити не вдалося.
Висновок. Таким чином, на підставі проведених на коліях підприємств промислового транспорту експериментальних досліджень встановлено параметри жорсткості елементів проміжних скріплень типу ДО, які дозволяють отримувати значення просторових жорсткостей цього скріплення залежно від рівня діючих навантажень і термінів експлуатації колії. 


\section{Список літератури}

1. Даренський, О.М. Математична модель просторових жорсткостей скріплення типу ДО [Текст] / О.М. Даренський // Зб. наук. праць. - Харків: УкрДАЗТ, 2013. - Вип. 136 - С. 227-231.

2. Даренський, O.M. Результаты експериментальних исследований работы железнодорожного пути промышленного транспорта [Текст] / O.М. Даренський // Зб. наук. праць. - Харків: УкрДАЗТ, 2011. - Вип. 125. - С. 35-45.

3. Система для вимірювання переміщень в елементах інженерних конструкцій і споруд під дією навантажень [Текст]: пат. №70477 України, МПК // GOДD 51500; У01 У 35100 / Даренський O.М., Астахов В.М., Вітольберг В.Г., Бугаєць Н.В., Беліков С.А.; заявник і патентовласник Українська державна академія залізничного транспорту. - № 4. - 2011 14768; заявл. 13.12.2011; опубл. 11.02.2012, Бюл. №11. - 5 с.

Ключові слова: параметри жорсткості проміжних скріплень типу ДО.

\section{Анотації}

Наведено результати експериментальних досліджень параметрів жорсткостей елементів проміжних скріплень типу ДО, які отримані для умов промислового залізничного транспорту.

Приведены результаты экспериментальных исследований параметров жосткостей элементов промежуточных скреплений типа ДО, полученных для условий промышленного железнодорожного транспорта.

The experimental results hardness intermediate fastening elements such as DO, obtained for an industrial railway. 